\title{
Diagnosis and tactics of surgical treatment of colorectal cancer that developed during pregnancy
}

\author{
I. K. Vytvytskyi ${ }^{1}$, O. O. Precel ${ }^{1}$, L. Yu. Lozynska ${ }^{2}$, S. O. Holovchanskyi ${ }^{1}$ \\ ${ }^{1}$ Lviv Regional Clinical Hospital, \\ ${ }^{2}$ Danylo Halytskyi Lviv National Medical University
}

\section{Діагностика і тактика хірургічного лікування колоректального раку, який розвинувся під час вагітності}

\author{
І. К. Витвицький ${ }^{1}$, О. О. Прецель ${ }^{1}$, Л. Ю. Лозинська ${ }^{2}$, С. О. Головчанський ${ }^{1}$ \\ ${ }^{1}$ Львівська обласна клінічна лікарня, \\ ${ }^{2}$ Львівський національний медичний університет імені Данила Галицького
}

The most common types of tumors, that develop during pregnancy, are breast, thyroid and epy reproductive system cancers. Of those, $15 \%$ of pregnancies end with spontaneous abortion. In total, cancers of different localization are found in 1: 1000 pregnant women $[1,2]$. The incidence of colorectal cancer (CRC) among pregnant women is 0.8 : 100,000 [3], and CRC is often diagnosed at a later stage [4]. Based on the analysis of the international database for the period of observation from 1998 to 2016, 41 pregnant women were registered, who developed CRC: $65.9 \%$ of women were diagnosed with colon cancer, and 34.1\% - rectal cancer. Progression of the disease was observed in $73.2 \%$ of women. Surgical treatment was performed for $51.2 \%$ of patients, for the rest - chemotherapy alone. Healthy children were naturally delivered in $80.5 \%$ of pregnant women, the rest - by cesarean section [3]. Almost 300 observations of CRC during pregnancy have been described in the world [4], and in Ukraine there is no information on the combination of CRC and pregnancy.

Clinical symptoms of CRC in pregnant women are characterized by intestinal motility disorders, nausea, weight loss, anemia, and weakness, blood or mucus in stool, abdominal pain. Most of these symptoms are masked by preeclampsia in the first and second trimesters of pregnancy. Fecal occult blood test (FOBT) is used as a screening to identify people at risk of developing $\mathrm{CRC}$. For patients with the positive result colonoscopy is performed. Determination of the level of cancer-embryonic antigen is not recommended for use as a screening test, as this indicator may be non-specifically elevated during pregnancy. Thus, the development of CRC during pregnancy constitutes a rare and a hard to study event, with the treatment strategy remain a complex issue. There is contradictory evidence regarding chemotherapy application during pregnancy. Although there are reports in the literature of the safe use of irinotecan and oxaliplatin in the second and third trimesters without adverse effects in the fetus [5 - 7]. Adjuvant radiation therapy may be used after a childbirth only [5]. Today, there is growing evidence of successful CRC treatment, which should be prescribed de- pending on the gestational age of the fetus, the tumor stage and indications for emergency or planned surgery [5, 8].

The study objective was to propose the strategy for diagnosis and surgical treatment of CRC, diagnosed during pregnancy and early lactation.

During the 17-year follow-up period, three pregnant women were registered in the Department of Proctology of the Lviv Regional Clinical Hospital, in whom CRC was detected. One woman was diagnosed at 4 to 5 weeks of gestation, and the other two were diagnosed on the 5 th and 35 th day after delivery, which may indicate a probably undiagnosed malignancy before pregnancy. The diagnosis of CRC was established using the following methods: physical examination, laboratory tests, fibrogastroscopy and colonoscopy. The ultrasound examination (ultrasound) of the abdominal cavity, X-ray of the chest (chest X-ray) and magnetic resonance imaging (MRI) were performed to determine the progression of the disease. Below we present a clinical observation.

A 34 years old woman, who became pregnant as a result of in vitro fertilization after 5 years of infertility treatment, was diagnosed with rectal cancer at a gestational age of 4 to 5 weeks. She had complaints of fresh blood during defecation and tenesmus. According to the patient, her mother and maternal grandfather also had CRC. A digital rectal examination have diagnosed a tumor of the rectum. Rectoromanoscopy on the posterior wall of the rectum revealed the lower edge of the exophytic tumor at a distance of $3 \mathrm{~cm}$ from the anorectal line with a diameter of $3 \mathrm{~cm}$. Highly differentiated adenocarcinoma was confirmed on histopathological examination. At fibrogastroscopy and colonoscopy (without anesthesia) no other neoplasia was found. Ultrasound showed no metastases in the liver and paraaortic lymph nodes. Xray of the thoracic cavity showed no pathology. The patient flatly refused to terminate the pregnancy.

At the beginning of the second trimester, at 13 to 14 weeks of gestation, MRI of the pelvis was performed and the tumor was found to grow into the muscular layer of the intestinal wall. One of the paraaortic lymph nodes was 
probably metastatic, making transrectal removal of the tumor impossible. At the 14 th -15 th week of pregnancy, the patient underwent surgery: laparotomy, low anterior resection of the rectum with D3 lymph node dissection and pull through coloanal anastomosis. In our opinion, this surgical strategy have minimized the need for the stoma creation to prevent complications, that may occur after ultra-low anterior resection of the rectum with a stapled anastomosis. According to the literature data, when diagnosing CRC at an early stage, surgery to preserve pregnancy is recommend$\mathrm{ed}$, and if there are signs of tumor invasion into neighboring structures or metastasis - the abortion, followed by complex oncological treatment [8].

Subsequent course of pregnancy was without complications. At the 38th week, laparotomy with cesarean section and revision of the abdominal organs was performed. There were no signs of the disease recurrence. The woman gave birth to a healthy boy with body weight $3200 \mathrm{~g}$, Apgar score 8 points. The patient refused to get adjuvant chemotherapy. It is believed that the method of a childbirth does not matter: it is possible both naturally and by cesarean section. In such cases, the operation for CRC can be combined with a cesarean section or postponed to reduce the size of the uterus [9], especially in the case of low rectal cancer. One month after, the patient underwent the excision of the sigmoid colon excess. Postoperative diagnosis: rectal cancer at a distance of $6 \mathrm{~cm}$ from anus, stage IIIA, clinical group III, T2N1M0G1R0. In the postoperative period the patient underwent regular endoscopic, radiological, laboratory examinations, including the levels of tumor markers. Currently, the function of the anal sphincter is good - it retains gases and liquid feces. The woman is raising a healthy son, who is 5 years old now.

Two other women were diagnosed with CRC immediately after giving birth to healthy children. Here we present the clinical cases.

A 37 years old pregnant woman underwent a cesarean section, and 5 days after delivery was diagnosed with sigmoid colon cancer stage II-III T4NXM0, complicated by intestinal obstruction and perforation. This patient was admitted urgently with complaints of lower left abdominal pain, general weakness and anemia. The operation was performed: urgent diagnostic laparoscopy; laparotomy; sigmoidectomy with the imposition of end-to-end descend-rectoanastomosis; drainage of the abdominal cavity. Pathological diagnosis: moderately differentiated adenocarcinoma that grows in all layers of the intestinal wall. The remaining lymph nodes showed signs of follicular hyperplasia and a sinus histocytosis of varying degrees of development. The patient received adjuvant chemotherapy.

According to the literature data, CRC is diagnosed in $54.5 \%$ of women only in the third trimester and in the early postpartum period [5].

A 43 years old woman was admitted to hospital 35 days after the birth of a child with complaints of weakness, anemia, bloody stool. Rectoromanoscopy was performed and a tumor measuring $3 \times 3 \mathrm{~cm}$ was found at a distance of 10 $\mathrm{cm}$ from the anus. The operation was performed: low anterior resection of the rectum with a stapled anastomosis. According to the results of pathological examination the diagnosis was adenocarcinoma with invasion into the submucosal and muscular layers - p'T3N0M0G1R0. The patient received adjuvant chemotherapy.

In both women the course of the postoperative period was uneventful. They are currently alive and raising healthy children, although the literature reports that patients with colorectal cancer have an unfavorable prognosis [5].

In recent years, there has been an increase in number of women with such kind of pathology, which is associated with increasing age of pregnant women, although in the presence of hereditary cancer syndromes, especially familial adenomatous polyposis, cancer develops at a relatively young age $-39.3( \pm 3.58)$ years [10]. With regard to nonpolyposis CRC (Lynch syndrome), the average age of manifestation of the disease is greater - $(50.27 \pm 9.41)$ years, although it is necessary to take into account the effect of anticipation when processing genealogical information [11]. Diagnosis of CRC should include the following stages: history, including careful analysis of genealogical information to identify individuals at risk of developing hereditary cancer syndromes; physical examination; endoscopic examinations; laboratory tests - detection of occult blood in the stool; in case of suspicion for Crohn's disease - determination of the $\mathrm{C}$-reactive protein and fecal calprotectin concentration; visualization of abdominal organs.

Thus, surgical treatment is risky both for preservation of pregnancy, and for a fetus. It is necessary to provide complete information to patients about the risk of tumor progression for immediate initiation of combined therapy. The decision to terminate a pregnancy after receiving information from the surgeon is personal to each woman. Depending on this, the strategy of further treatment is determined. Treatment of CRC in pregnant women is individual, depending on whether the woman insists on maintaining the pregnancy after receiving objective information about the disease. The operation (laparotomy, low anterior resection of the rectum with D3 lymph node dissection with pullthrough colo-anal anastomosis) minimizes the need for the stoma creation to prevent complications, that may occur after low anterior resection of the rectum with stapled anastomosis. Adjuvant chemotherapy is recommended in the second and third trimesters after the patients' agreement achieved.

Financing. The study was funded by the authors.

Contribution of each participant. Vytvytsky IK - collection and processing of materials, conclusions; Pretsel OO, Golovchansky SO - participation in operations, management of patients, analysis of the received data; Lozynska L. Yu. - concept of work, literature review, writing the article.

Conflict of interest. The authors state that they have no conflict of interest. 
Consent to publication. All authors approved this manuscript and its publication.

\section{References}

1. Pentheroudakis G, Pavlidis N. Cancer and pregnancy: poena magna, not anymore. Eur J Cancer. 2006 Jan;42(2):126-40. doi: 10.1016/j. ejca.2005.10.014. Epub 2005 Dec 2. PMID: 16326099.

2. Protasova AE, Protasov DA. Rare combinations malignant tumors and pregnancy. Practical oncology. 2009;10(4): 216-27. Russian.

3. Kocián P, de Haan J, Cardonick EH, Uzan C, Lok CAR, Fruscio R, et al. Management and outcome of colorectal cancer during pregnancy: report of 41 cases. Acta Chir Belg. 2019 Jun;119(3):166-75. doi: 10.1080/00015458.2018.1493821. Epub 2018 Jul 16. PMID: 30010511 .

4. Bernstein MA, Madoff RD, Caushaj PF. Colon and rectal cancer in pregnancy. Dis Colon Rectum. 1993 Feb;36(2):172-8. doi: 10.1007/ BF02051174. PMID: 8425421.

5. Habidze DL, Panov VV, Saidov VYa, Saenko VV, Posochov DN. Features of diagnosis and treatment of colorectal cancer during pregnancy. Health of ukraine. Gastroenterology, hepathology, coloproctology. 2015;(3):50-1. Russian.

6. Cirillo M, Musola M, Cassandrini PA, Lunardi G, Venturini M. Irinotecan during pregnancy in metastatic colon cancer. Tumori. 2012 Nov;98(6):155e-7e. doi: 10.1700/1217.13511. PMID: 23389374.
7. Dogan NU, Tastekin D, Kerimoglu OS, Pekin A, Celik C. Rectal cancer in pregnancy: a case report and review of the literature. J Gastrointest Cancer. 2013 Sep;44(3):354-6. doi: 10.1007/s12029 012-9463-5. PMID: 23196388.

8. Smirnov AV, Berelavichus SV, Dubrovsky AV, Petrov DIu, Kalinin DV, Kriger AG. Colorectal cancer in pregnant women. Khirurgiya. 2015;(5):83-5. Russian. doi: 10.17116/hirurgia2015583-85.

9. Khodaverdi S, Kord Valeshabad A, Khodaverdi M. A Case of Colorectal Cancer during Pregnancy: A Brief Review of the Literature. Case Rep Obstet Gynecol. 2013;2013:626393. doi: 10.1155/2013/626393. Epub 2013 Jan 14. PMID: 23401815; PMCID: PMC3557611.

10. Lozynska MR. The role of genetic factors in intestinal diseases with a high risk of colorectal cancer. DSci(Biol) [thesis]. Kyiv; 2015. 40 p. Ukrainian.

11. Lozynska M, Fedota O, Lozynska L, Prokopchuk NM, Pinyazhko RO. Distribution characteristics of colorectal cancer patients for gender and age depending of hereditary predisposition to the disease. Oncology. 2016;18(2):104-9.

Received: 12.01 .2021 